\title{
Submarine landform assemblages and sedimentary processes related to glacier surging in Kongsfjorden, Svalbard
}

\author{
Katharina Streuff ${ }^{1,2} \cdot$ Matthias Forwick $^{1}$ - Witold Szczuciński ${ }^{3}$. \\ Karin Andreassen ${ }^{1,4} \cdot$ Colm Ó Cofaigh ${ }^{2}$
}

Published online: 21 November 2015

(C) The Author(s) 2015. This article is published with open access at Springerlink.com

\begin{abstract}
High-resolution swath-bathymetry data from inner Kongsfjorden, Svalbard, reveal characteristic landform assemblages formed during and after surges of tidewater glaciers, and provide new insights into the dynamics of surging glaciers. Glacier front oscillations and overriding related to surge activity lead to the formation of overridden moraines, glacial lineations of two types, terminal moraines, associated debris lobes and De Geer moraines. In contrast to submarine landform assemblages from other Svalbard fjords, the occurrence of two kinds of glacial lineations and the presence of De Geer moraines suggest variability in the landforms produced by surge-type tidewater glaciers. All the landforms in inner Kongsfjorden were deposited during the last c. 150 years. Lithological and acoustic data from the innermost fjord reveal that suspension settling from meltwater plumes as well as ice rafting are dominant sedimentary processes in the fjord, leading to the deposition of stratified glacimarine muds with variable numbers of clasts. Reworking of sediments by glacier surging results in the deposition of sediment lobes containing massive glacimarine muds. Two sediment
\end{abstract}

Katharina Streuff

katharina.streuff@durham.ac.uk

1 Department of Geology, UiT-The Arctic University of Norway, Postboks 6050, 9037 Langnes, Troms $\varnothing$, Norway

2 Present Address: Department of Geography, Durham University, Science Site, South Road, Durham DH13LE, UK

3 Institute of Geology, Adam Mickiewicz University in Poznań, Maków Polnych 16, 61-606 Poznań, Poland

4 Department of Geology, CAGE-Centre for Arctic Gas Hydrate, Environment and Climate, UiT-The Arctic University of Norway, Postboks 6050, 9037 Langnes, Troms $\emptyset$, Norway cores reveal minimum sediment accumulation rates related to the Kongsvegen surge from 1948; these were $30 \mathrm{~cm} \mathrm{a}^{-1}$ approximately $2.5 \mathrm{~km}$ beyond the glacier front shortly after surge termination, and rapidly dropped to an average rate of $1.8 \mathrm{~cm} \mathrm{a}^{-1}$ in $\sim 1950$, during glacier retreat.

Keywords Submarine landforms - Glacier surges · Tidewater glaciers · Multibeam bathymetry $\cdot$ Lithology . Svalbard

\section{Introduction}

Glacier surges are cyclic switches between active and passive phases, during which the ice front may either advance rapidly (active), stagnate (transition), or retreat slowly (passive/quiescent phase; e.g. [16, 34, 60, 68, 71]). They generally occur independently of climate and are triggered internally through, for example, changes in glacier hydrology or basal thermal regime [44, 60, 68, 72]. Surges are common on Svalbard, where they have a generally longer duration than elsewhere, with active phases of between 4 and 10 years and quiescent phases of between 50 and 500 years $[5,15,61]$. Many Svalbard glaciers have been identified as surge-type (e.g. [15, 35, 53, 63, 66, 67]), with surges well-documented from the past c. 180 years, but only two older examples (Paulabreen and Nathorstbreen; [35, 36, 46, 49, 53]).

Glacier surges lead to the formation of characteristic landform assemblages, which are revealed when the glaciers retreat (e.g. [10, 20, 22, 25, 63, 66, 71, 73]). Landforms related to glacier surges in submarine settings have been described from several Spitsbergen fjords [3, 10, 29, 63, 66, 67]. The landform models suggested thus far include overridden recessional moraines, (mega-scale) glacial 
lineations, terminal moraines with associated sediment lobes on their distal slopes, eskers, annual push moraines and crevasse-squeeze ridges, the latter suggested to be the only feature diagnostic of a glacier surge $[66,71]$. The high detail preserved in submarine environments offers invaluable insights into the processes controlling landform genesis, and, together with lithological records from sediment cores, enables a better understanding of tidewater glacier sedimentation and dynamics (e.g. [10, 63, 66]).

In this paper we present acoustic data (swath bathymetry and high-resolution seismic data) and lithological analyses of two sediment cores from inner Kongsfjorden, Svalbard. We describe and interpret submarine landform assemblages and deposits related to glacier surges and show that such assemblages are more diverse than previously suggested.

\section{Study area}

Kongsfjorden is located on northwestern Spitsbergen, the largest island of the Svalbard archipelago. It is the southern branch of the Kongsfjorden-Krossfjorden fjord system $\left(78^{\circ} 50^{\prime} \mathrm{N}, 11^{\circ} 40^{\prime} \mathrm{E}\right.$, and $79^{\circ} 04^{\prime} \mathrm{N}, 12^{\circ} 40^{\prime} \mathrm{E}$; Fig. 1). Kongsfjorden and Krossfjorden merge towards the open sea, where a large submarine trough, Kongsfjordrenna, channelled fast-flowing ice streams during the last glacial (e.g. [40, 64]). Kongsfjorden is approximately $20 \mathrm{~km}$ long and between 4 and $10 \mathrm{~km}$ wide. It covers an area of $\sim 210 \mathrm{~km}^{2}$, and has a volume of $29.4 \mathrm{~km}^{3}$ [41]. Water depths range from $350 \mathrm{~m}$ in the outer and central parts to $<100 \mathrm{~m}$ in the inner fjord. A detailed review on Kongsfjorden's climate and oceanography was provided by Svendsen et al. [78].

Seven tidewater glaciers terminate in Kongsfjorden: Løvlandbreen and Svansbreen form one tidewater front with Blomstrandbreen in the north of the fjord (Fig. 1) and will be summarized by the term "Blomstrandbreen" throughout this paper. Conwaybreen, Kongsbreen and Kronebreen dominate the east of the fjord with Kongsbreen terminating as two tidewater margins, one north and one south of Ossian Sarsfjellet (Fig. 1). Kongsvegen flows into the fjord from the south-east, adjacent to Kronebreen (Fig. 1). Three of these glaciers have been documented to be of surge-type, with Kronebreen and Kongsvegen experiencing respective surges in 1869 and 1948, and Blomstrandbreen surging in 1960 [35, 54].

\section{Glacial history}

The glacial history of the Svalbard archipelago during and since the Late Weichselian is documented to have occurred in three main stages: (a) ice advance, (b) full glaciation during the Last Glacial Maximum (LGM), and (c) ice retreat (see e.g. [19, 43, 50]).

During initial advance, ice extended beyond the present coastline, reaching the shelf break between 24,080 \pm 150 and $23,550 \pm 185$ cal a BP (calibrated years before present; [43, 50]). Fast-flowing ice streams drained the Svalbard-Barents Sea Ice-Sheet via the main fjord systems on Svalbard, including Kongsfjorden (e.g. $[40,64,65])$. A terminal moraine at the shelf break in southern Kongsfjordrenna was inferred to reflect maximum ice extent during the Late Weichselian [65]. Deglaciation of the shelf and fjords on west Spitsbergen began around 20,500 $\pm 500 \mathrm{cal}$ a BP and was interrupted by multiple glacier halts and/or re-advances (e.g. [3, 31, $32,43,46,65])$. The deglaciation of Kongsfjorden proper was documented as a two-stage recession initiated $\sim 13,000$ cal a BP, leading to ice-free conditions by approximately 9000 cal a BP [52]. Recent findings by Henriksen et al. [37], however, show that the ice stream in Kongsfjorden had retreated to the fjord mouth by 16,600 cal a BP, and that the deglaciation of the areas west of Blomstrandhalvøya was already complete before $14,400( \pm 300)$ cal a BP.

Asynchronous re-growth of Svalbard glaciers occurred after c. 9000 cal a BP (e.g. [3, 30, 31, 33]). Maximum Late Holocene glacier extents occurred either due to climatic cooling during the Little Ice Age or due to glacier surges (e.g. [15, 35, 46, 53, 58, 63, 66, 67]).

\section{Methods}

Swath-bathymetry, sub-bottom profiler (chirp) data and sediment cores acquired in autumn 2010 with R/V Jan Mayen (now R/V Helmer Hanssen) from inner Kongsfjorden provide the basis for this study (Fig. 1). A Kongsberg Maritime Simrad EM 300 multibeam echo sounder was used to acquire the bathymetry data (max. resolution of $5 \mathrm{~m}$ ). The instrument operated at a frequency of approximately $30 \mathrm{kHz}$ and was calibrated using p-wave velocities for the water column obtained from CTD (conductivity, temperature, depth) measurements. The bathymetry data were supplemented with multibeam data from the Norwegian Hydrographic Survey gridded to a max. resolution of $5 \mathrm{~m}$ and visualized and interpreted using the Fledermaus v7 3D Visualization and Analyzing Software. Chirp data are exclusively available for the innermost part of Kongsfjorden (Fig. 1c), where profiles were recorded using a hull-mounted EdgeTech 3300-HM sub-bottom profiler operating at a pulse mode of $2-12 \mathrm{kHz}$ and $3 \mathrm{~ms}$, while the ping rate was set to $1.9 \mathrm{~Hz}$. The profiles were processed in the EdgeTech Software and interpreted using SMT The Kingdom Suite. 
Fig. 1 a Map of Spitsbergen with red rectangle indicating the extent of $\mathbf{b}$ bathymetry available for this study and surrounding areas. 1 Breøyane, 2 Gerdøya, 3 Løvenøyane. Black dots indicate location of the two sediment cores 10JMGlaciBar-GC01 (south) and 10JM-GlaciBar-GC02 (north). Satellite imagery downloaded from Svalbardkartet.

c Locations and extent of available chirp lines, with bright green lines showing the location of profiles in Fig. 6. The colour scale indicates water depth and refers to both, $\mathbf{b}$ and $\mathbf{c}$

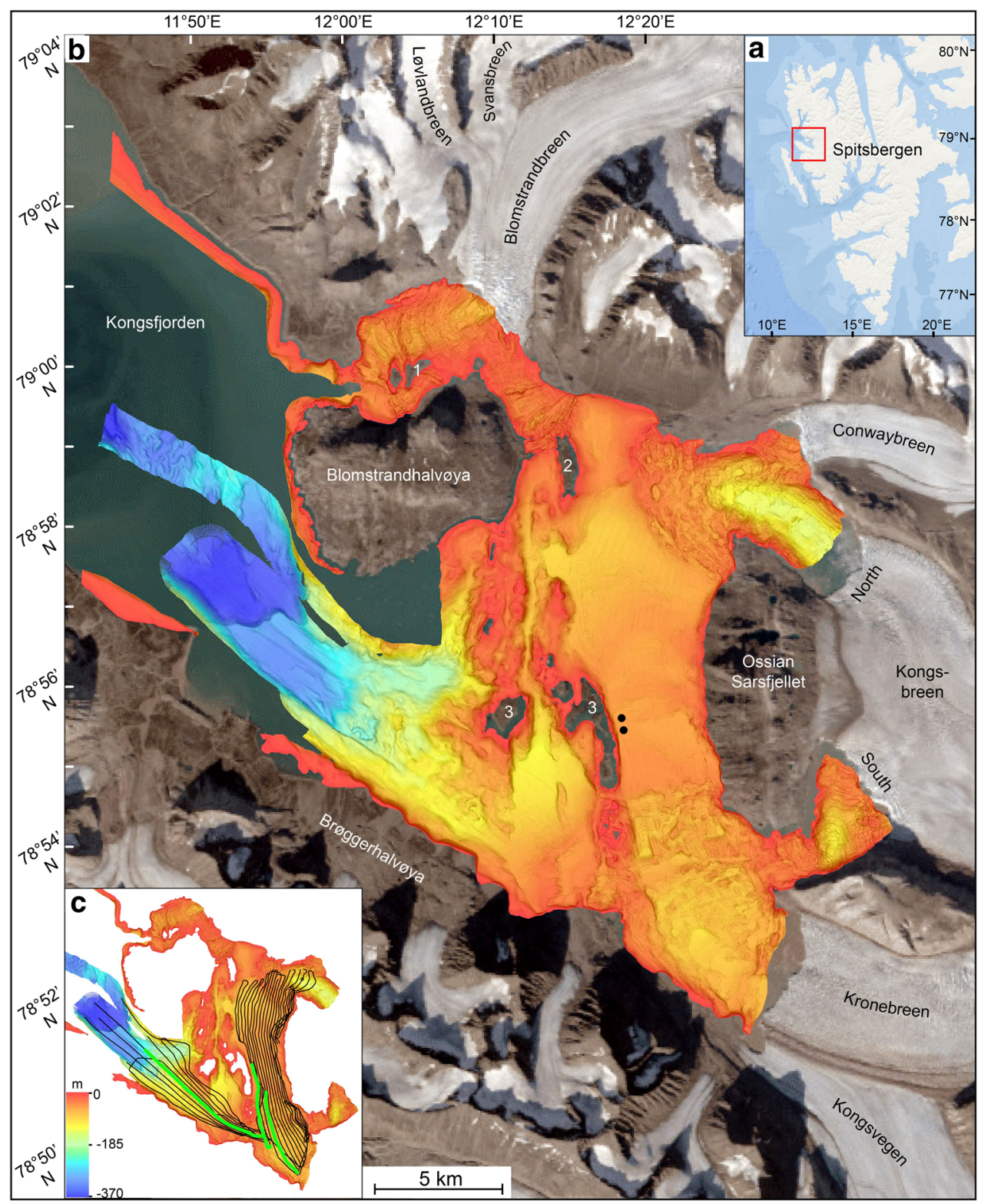

Two gravity cores, 10JM-GlaciBar-GC01 (GC01) and 10JM-GlaciBar-GC02 (GC02), were retrieved with a $1900 \mathrm{~kg}$ heavy gravity corer with a $6 \mathrm{~m}$ long barrel. After retrieval the cores were divided into sections of up to $1 \mathrm{~m}$ in length and were subsequently stored at $+4{ }^{\circ} \mathrm{C}$. The core sites are located $\sim 310 \mathrm{~m}$ apart from each other, with GC01 $\left(78^{\circ} 55^{\prime} 50^{\prime \prime} \mathrm{N}, 12^{\circ} 20^{\prime} 49^{\prime \prime}\right.$ E; $50 \mathrm{~m}$ water depth; $286 \mathrm{~cm}$ length) recovered from the top of a sediment wedge (representing a debris lobe deposited from a glacier surge, see section "Results and interpretations" below), and GC02 $\left(78^{\circ} 55^{\prime} 59^{\prime \prime} \mathrm{N}, 12^{\circ} 20^{\prime} 36^{\prime \prime} \mathrm{E} ; 53 \mathrm{~m}\right.$ water depth; $339 \mathrm{~cm}$ length) from c. $130 \mathrm{~m}$ beyond this wedge (Fig. 1b). The p-wave velocity of the sediments was measured in $1 \mathrm{~cm}$ increments using a GEOTEK multi-sensor core logger (MSCL) at UiTThe Arctic University of Norway prior to opening of the cores. Lithological logs are based on visual descriptions of the sediment surfaces as well as X-radiographs taken with a Philips Macrotank (5 mA; $80 \mathrm{kV}$; exposure times: $100 \mathrm{~s}$ to 4 min). Color images were acquired with a Jai L-107CC 3 CCD RGB Line Scan Camera installed on an Avaatech XRF core scanner. Sediment samples $(\sim 1 \mathrm{~g}$ every $10 \mathrm{~cm})$ were measured with a Beckman Coulter LS13320 Laser Diffraction Particle Size Analyzer to obtain information on grain size distribution. Prior to measurements each sample was dissolved in $50 \mathrm{ml}$ of water and homogenized in a shaker.

Sediment accumulation rates (SAR) for the last century were determined through complementary ${ }^{210} \mathrm{~Pb}$ and ${ }^{137} \mathrm{Cs}$ analyses, as previously used for Svalbard fjords [78, 81, 84, 85]. Activities of both isotopes were measured with gamma spectroscopy using a Canberra GX2520 high-purity coaxial 
germanium detector at the Institute of Geology, Adam Mickiewicz University in Poznań, Poland. For this, sediment samples of about $20 \mathrm{~g}$ were taken from $10 \mathrm{~cm}$ thick intervals, dried and ground. Obtained activities were decay-corrected to the date of sampling, and the results are presented with a two-sigma standard deviation uncertainty range. From the decrease of excess ${ }^{210} \mathrm{~Pb}$ activities with sediment depth, SAR could be calculated (following [59]). Excess ${ }^{210} \mathrm{~Pb}$ activities were determined by taking the average supported activity from the sample below the region of radioactive decay, and subtracting it from the total activity. The independent SAR assessment was made using the first occurrence of ${ }^{137} \mathrm{Cs}$ as a marker of the early 1950s (taken as 1952), its maximum activity peak as $\sim 1962$ and the younger secondary activity peak as Chernobyl-related 1986 (e.g. [2, 69]). However, due to the possible loss of the core top sediment during the coring process, sediment mixing, variations in sediment accumulation rates and low activities of excess ${ }^{210} \mathrm{~Pb}$, the calculated sediment accumulation rates should be treated as approximate values.

A digital terrain model (DTM) from 2009 with a vertical resolution of $5 \mathrm{~m}$ (Delmodell 5m 2009_13822_33, courtesy of the Norwegian Polar Institute, provided on geodata.npolar.no) was supplemented with satellite imagery available on Google Earth (August 2015) and visualized in Esri ArcMap 10.2. Superficial crevasses were then mapped on all tidewater glaciers in Kongsfjorden within $\sim 1 \mathrm{~km}$ of the current glacier fronts.

\section{Results and interpretations}

\section{Seafloor morphology}

Landforms occurring in Kongsfjorden are described and interpreted in the following section. Their distribution is shown in Fig. 2.

\section{Large transverse ridges: overridden moraines}

10-30 m high ridges are orientated generally transverse to the direction of ice flow and occur in front of Kronebreen/ Kongsvegen and Blomstrandbreen (Fig. 2b). They are up to $300 \mathrm{~m}$ wide and around $1 \mathrm{~km}$ long. Their crests are round, smooth, cross-cut by streamlined bedforms (section "Streamlined bedforms: glacial lineations") and are overprinted by small sharp-crested transverse ridges (section "Small, predominantly transverse ridges: De Geer moraines").

The large ridges are very similar to transverse ridges from Borebukta [63] and are thus interpreted to be moraines deposited by a tidewater glacier during an earlier phase of stagnation or retreat. These ridges were then overridden during a subsequent advance, leading to the formation of the streamlined bedforms described in section "Streamlined bedforms: glacial lineations". The occurrence of several of these moraines in front of Kronebreen and Kongsvegen (Figs. 2b, 3a) suggests that here they represent recessional moraines deposited from repeated stillstands during overall retreat of the glacier. The single ridge in front of Blomstrandbreen (RB2, Fig. 2b), however, probably represents a terminal moraine (cf. section "Large transverse ridges and lobe-shaped deposits: terminal moraines and debris lobes" below) from an earlier advance.

\section{Streamlined bedforms: glacial lineations}

Two types of streamlined bedforms are distinguished: (1) sets of parallel, $8 \mathrm{~m}$ high, $20-80 \mathrm{~m}$ wide, and up to $2 \mathrm{~km}$ long smooth-crested grooves and ridges, aligned parallel to the direction of ice flow (Figs. 2b, 3c) and (2) sets of parallel, $\sim 2 \mathrm{~m}$ high, $\sim 20 \mathrm{~m}$ wide and up to $600 \mathrm{~m}$ long sharp-crested grooves and ridges, also aligned parallel to the direction of ice flow and spaced at variable distances between 50 and $300 \mathrm{~m}$ (Figs. 2b, 3e). These latter features are confined to the areas in front of Kongsbreen North and Kronebreen/Kongsvegen, whereas the smoother grooveridge features occur in front of Blomstrandbreen, Conwaybreen and Kongsbreen South. Similar features also appear in the outer fjord where they were likely formed during the last glacial (Fig. 2b, [57]). With the exception of these latter features, all streamlined bedforms in Kongsfjorden are overprinted by small, transverse ridges (see section "Small, predominantly transverse ridges: De Geer moraines").

The two types of streamlined bedforms in Kongsfjorden are interpreted to be glacial lineations. Based on appearance and dimensions, the grooves and ridges are similar to (mega-scale) glacial lineations (MSGLs; e.g. [1, 3, 12, 29, $63,64,76])$, which are closely associated with fast ice-flow [47]. Even though lineations in Kongsfjorden are much shorter (max. $2 \mathrm{~km}$ ) than MSGLs described from elsewhere (up to $70 \mathrm{~km}$; [11]), the majority have elongation ratios of 10:1 or greater, technically classifying them as MSGLs. We infer that the Kongsfjorden lineations resulted from the same processes forming MSGLs, i.e. fast ice-flow (e.g. [76]), when processes of erosion and re-deposition deform soft subglacial sediments into sets of grooves and ridges (cf. e.g. [47, 62, 66, 83]). In Kongsfjorden fast ice flow was probably due to the onset of the active phase of a glacier's surge-cycle. We note, however, that the differences in size and crest morphology between the two lineation types in Kongsfjorden indicates that their formation probably occurred under slightly different conditions. This issue is further discussed in section "Surge signatures in 

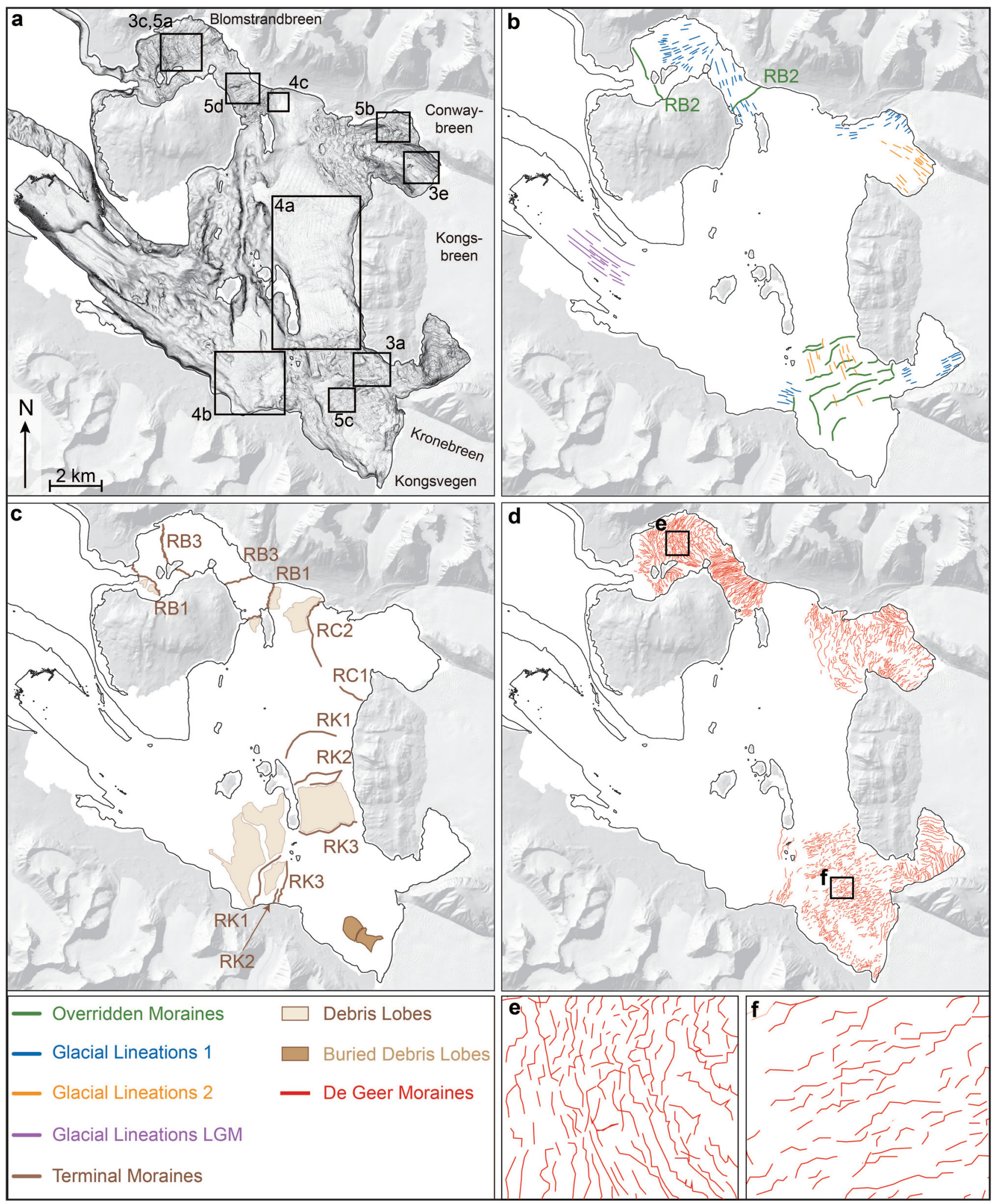

Fig. 2 Distribution of the interpreted landforms in Kongsfjorden. a Overview of the bathymetry relief and indication of the locations for subsequent figures; $\mathbf{b}$ map of overridden moraines and glacial lineations; $\mathbf{c}$ map of terminal moraines and debris lobes; $\mathbf{d}$ map of

De Geer moraines in the fjord, with indications of locations of the zoom-ins e and f. Maps in this paper were created using a Svalbard DTM, available online from the Norwegian Polar Institute 
Fig. 3 The locations of all subfigures are outlined in Fig. 2a. a Shaded relief image of the bathymetry showing overridden moraines in front of Kronebreen/Kongsvegen, which are overprinted by streamlined bedforms and small transverse ridges. b Profile $A-A^{\prime}$ from proximal to distal across overridden moraines. c Grooveridge features in front of Blomstrandbreen with the profile $C-C^{\prime}$ across them shown in d. e Small streamlined ridges in front of Kongsbreen North.

The profile $E-E^{\prime}$ across them is shown in $\mathbf{f}$

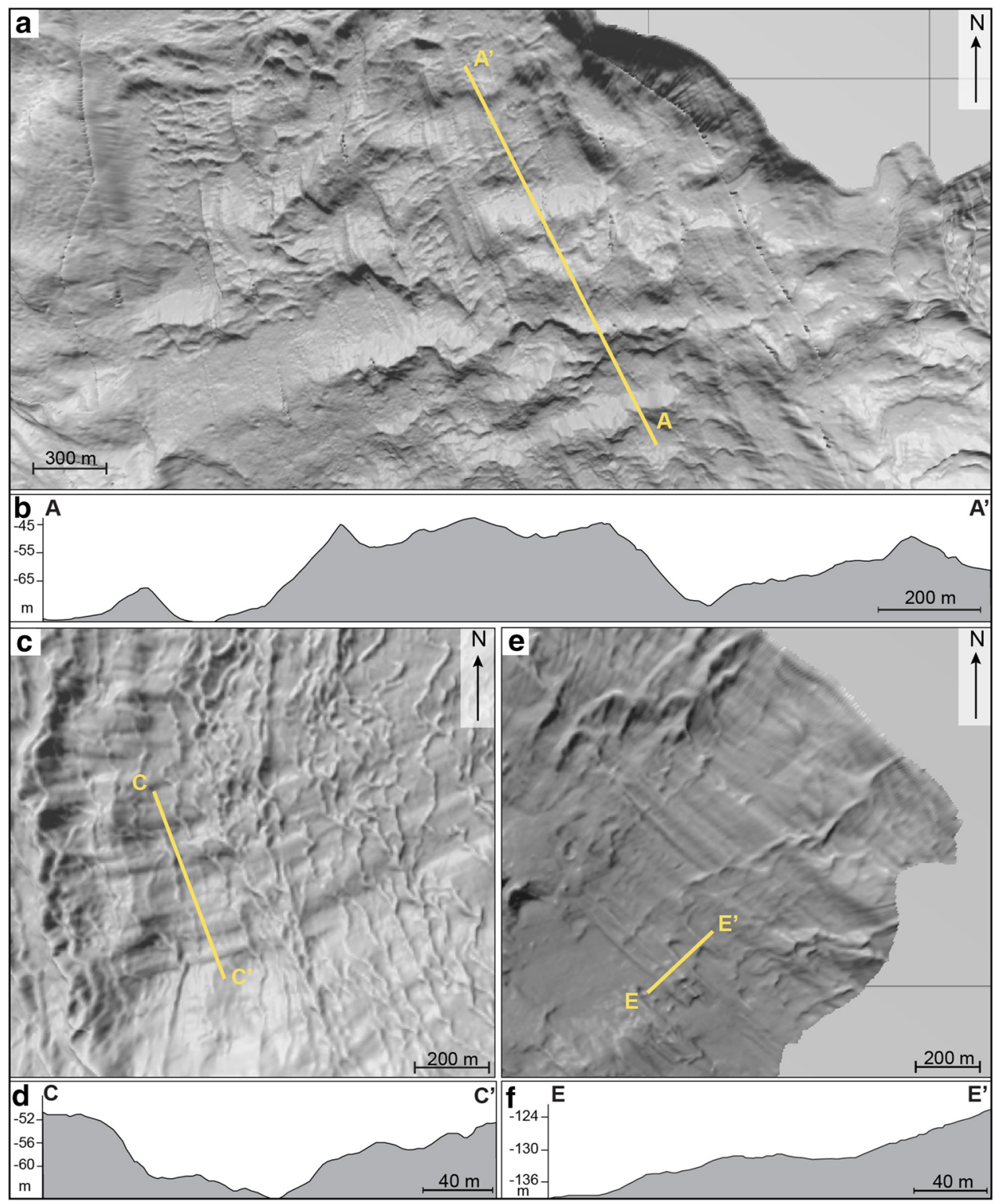

Kongsfjorden and comparison with other Spitsbergen fjords" below.

All glacial lineations in inner Kongsfjorden are inside the respective glaciers' maximum extents, so we interpret them to have formed within the last $\sim 150$ years (see section "Timing of landform formation" below).

\section{Large transverse ridges and lobe-shaped deposits: terminal moraines and debris lobes}

Seven large transverse ridges occur in Kongsfjorden, three in front of Blomstrandbreen (RB1, RB2 (overridden), RB3; numbered from distal to proximal, Fig. 2b, c), two in front of Conwaybreen and Kongsbreen North (RC1 and RC2) and three in front of Kronebreen and Kongsvegen (RK1,
RK2 and RK3; Fig. 2c). They are 15-35 m high, between 500 and $2000 \mathrm{~m}$ long and several hundred meters wide (Fig. 4). Ridges in front of Blomstrandbreen and Kronebreen/Kongsvegen are separated into several segments by the surrounding islands (Fig. 2c). The ridges occur at distances of between 3 and $9 \mathrm{~km}$ from the present ice margins and are characterized by generally steeper proximal and gentler distal flanks (Fig. 4 d, e). RB3 differs from the other ridges by being symmetrical in cross-section and narrower (max. $100 \mathrm{~m}$ ); it also has a much sharper crest (see Fig. 5d). With the exception of RB3 and RC1 the ridges occur in close association with lobe-shaped deposits on their distal flanks (Figs. 2c, 4b, c). These lobes occur as single deposits (up to $360 \mathrm{~m}$ wide and $600 \mathrm{~m}$ long) or in sets of (partly superimposed) tongue-shaped landforms. The latter can 


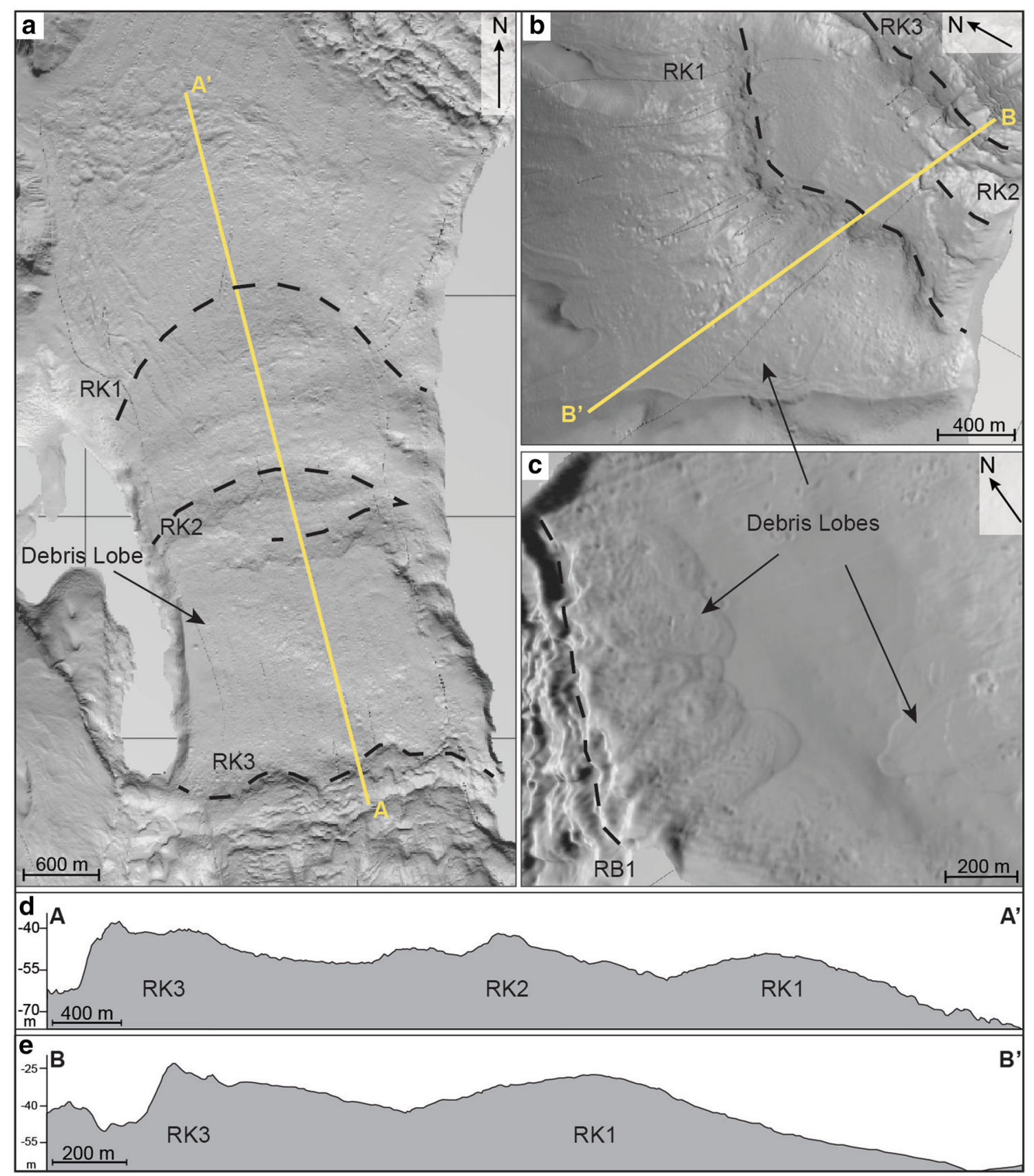

Fig. 4 The locations of all subfigures are outlined in Fig. 2a. a Shaded relief image of the bathymetry showing three terminal moraines in front of Kronebreen/Kongsvegen ( $R K 1, R K 2$ and $R K 3)$, with $R K 1$ marking the most distal moraine. b Terminal moraines $R K 1$, 2 and 3 west of Kronebreen/Kongsvegen. The large debris lobe

cover areas of up to $5 \mathrm{~km}^{2}$. The lobes typically occur at water depths between 15 and $50 \mathrm{~m}$, but one lobe in the southwestern part of the fjord extends down to c. $110 \mathrm{~m}$.

In front of the Kronebreen/Kongsvegen ice margin two lobes have very similar characteristics, but are dissociated from terminal moraines (Fig. 2c). They are separated by an approximately $3 \mathrm{~m}$ high elevation. Both features are located directly at the glacier margin and cover areas of 0.06 associated with RK1 is also visible. c Debris lobes off Blomstrandbreen's and Conwaybreen's outermost moraines, RB1 and RC2. Water depths range from -15 to $-50 \mathrm{~m}$. $\mathbf{d}$ and $\mathbf{e}$ show profiles $A-A^{\prime}$ and $B-B^{\prime}$, respectively, across $R K 1, R K 2$ and $R K 3$ from proximal to distal

$\mathrm{km}^{2}\left(380 \times 160 \mathrm{~m}^{2}\right)$ and $0.04 \mathrm{~km}^{2}\left(500 \times 85 \mathrm{~m}^{2}\right)$, respectively. Chirp data reveal that these features are buried beneath stratified sediments (cf. section "Seismostratigraphy”, Fig. 6c).

The large transverse ridges are inferred to be terminal moraines marking the maximum extent of, in most cases several, glacier advances. These ridges could be of glaciotectonic origin and reflect pushed-up, folded and/or 


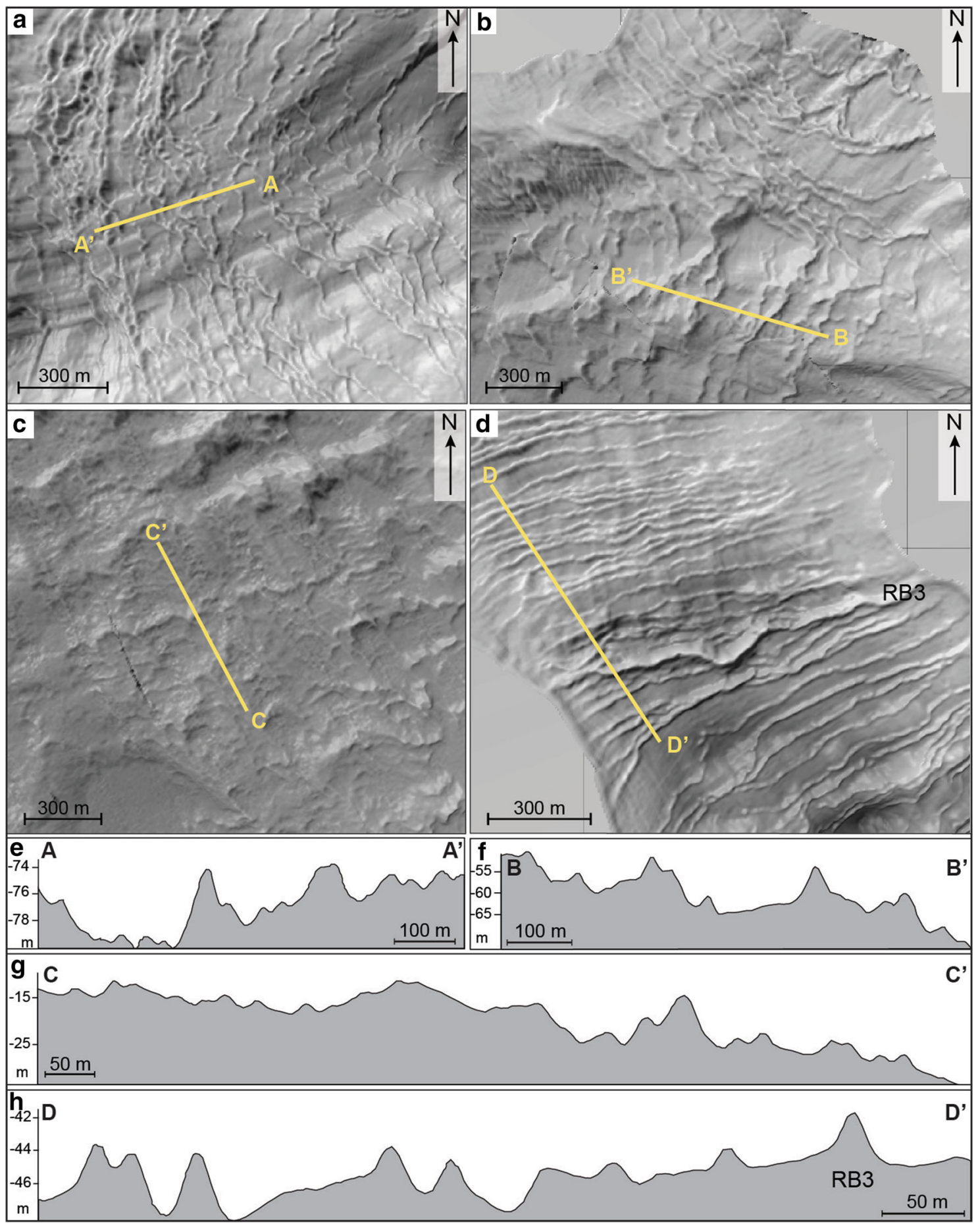

Fig. 5 The locations of all subfigures are outlined in Fig. 2a. Shaded relief image of the bathymetry showing the different appearance of De Geer moraines in Kongsfjorden in front of a Blomstrandbreen, b Conwaybreen, c Kronebreen/Kongsvegen and d southeast of

thrust sub- or proglacial sediments, as described for other areas on Svalbard (e.g. [9, 10, 57, 63, 66, 67, 74]). We suggest that the lobe-shaped landforms are debris lobes that represent either (1) a product of downslope mass-transport of glacigenic sediment deposited from quasi-continuous
Blomstrandbreen. d Also shows the large moraine ridge RB3. Cross-sectional profiles across the features from proximal to distal are shown in $\mathbf{e}-\mathbf{h}$ respectively

slope failure on the distal side of the moraine during or after maximum ice extent, or (2) glacier-outwash fans formed by meltwater-related processes during maximum extent of the glacier (e.g. [10, 49, 66, 67]). The sedimentary lobes in front of Kronebreen/Kongsvegen were probably 
formed from continuous high sediment supply from meltwater streams (cf. [45, 82]) and may indicate that the Kronebreen/Kongsvegen margin experienced a prolonged still-stand close to its 2010 position.

\section{Small, predominantly transverse ridges: De Geer moraines}

Numerous small ridges, that are $1-5 \mathrm{~m}$ high, several hundred meters long, and around $30 \mathrm{~m}$ wide (Figs. 2d, 5), are observed in Kongsfjorden. Although generally transverse and (sub-)parallel to each other, they have variable orientations and, in some cases, have a "saw-tooth" pattern in planform (Fig. 2e, f). Individual ridges cross-cut each other in places, are spaced at irregular intervals between 5 and $100 \mathrm{~m}$ and can exhibit branching. They occur in water depths down to $150 \mathrm{~m}$ and have mostly sharp, symmetrical crests (Fig. 5). Some ridges are longer and straighter than others, may extend across the entire width of the fjord and have slightly sinuous crests orientated exclusively perpendicular to the direction of ice flow (Fig. 5d). About 55 of these latter ridges occur in the fjord basin southeast of Blomstrandbreen, where they have been deposited between the outermost terminal moraine and the current ice front (Fig. 2d). 45 ridges or segments thereof extend between the outermost moraine and the current ice front of Conwaybreen, whereas about 30 ridges were deposited in the proximal basin of Kongsbreen South (Fig. 2d). In front of Kronebreen/Kongsvegen, most of the small ridges are around $1 \mathrm{~m}$ high and show weakly defined crests and frequent changes in orientation (Fig. 5c, g).

Based on their dimensions and morphology the small ridges are interpreted as De Geer moraines (e.g. [14, 86]). De Geer moraines form subaquatically and typically occur as sets of transverse, parallel, irregularly spaced ridges that are around $3 \mathrm{~m}$ high, several hundred $\mathrm{m}$ long and up to 30 $\mathrm{m}$ wide $[56,86]$. Two main mechanisms have been proposed for their formation: (1) the ridges are annual end moraines composed of subglacial sediment pushed up at the glacier grounding line (e.g. [7, 9, 14, 51, 75]); (2) they are the product of sediment squeezed into basal crevasses (e.g. [4, 38, 77, 86]). In Svalbard, similar ridges have been interpreted as either annual push moraines, created in front of tidewater glaciers by pushing during small winter readvances, or as crevasse-squeeze ridges [29, 63, 66, 71]. As glaciers are believed to be especially crevassed when in the active phase of a surge cycle, the crevasse-squeeze ridges have been suggested to be the only landform definitively indicative of surge activity [63, 71]. Following the recommendation of Lundqvist [55], we interpret the small ridges in Kongsfjorden as De Geer moraines. Although they could have been formed by either of the two suggested mechanisms (see above), we favour formation related to crevasse-squeezing. This issue is further discussed in section "Surge signatures in Kongsfjorden and comparison with other Spitsbergen fjords" below.

\section{Seismostratigraphy}

Chirp data reveal four acoustic facies in inner Kongsfjorden (Fig. 6). Facies 4 is stratigraphically oldest and is characterized by (semi-)transparent, acoustically massive reflections. It occasionally crops out along steeper slopes (Fig. 6). The thickness of Facies 4 ranges from $1-10 \mathrm{~ms}$ (two-way travel time-TWT), which converts to about 1-8 $\mathrm{m}$, respectively (using $1500 \mathrm{~m} \mathrm{~s}^{-1}$ for all facies, the $\mathrm{p}$-wave velocity determined from MSCL measurements). These are minimum thicknesses, however, as the max. penetration of the echosounder signal is $\sim 26 \mathrm{~ms}$ TWT, i.e. $\sim 20 \mathrm{~m}$. Facies 3 is acoustically similar to Facies 4 and shows weak massive reflections. However, Facies 3 appears thicker than Facies 4 (min. 10-20 ms or 8-15 m thick) and has a wedgelike shape (as indicated by brown polygons in Fig. 6). Facies 3 only occurs on slopes, specifically the distal sides of terminal moraines, and close to the Kronebreen/ Kongsvegen ice margin. It appears thicker at the foot of the slopes, where it generally onlaps onto Facies 4. However, on the distal side of RK3 it onlaps onto Facies 2 (Fig. 6b, d). Facies 2 is acoustically stratified with laterally (semi)continuous, opaque, parallel reflections of variable strength (Fig. 6b, d). The facies is bounded by a variably strong, opaque, semi-continuous reflection at its top, which is largely parallel to the seabed, and a weaker semi-continuous reflection at its base. Facies 2 is around $5 \mathrm{~ms}(\sim 4$ $\mathrm{m}$ ) thick and shows a downlapping character in some areas in Kongsfjorden (Fig. 6b, d). Facies 1 is similar to Facies 2, with parallel, (semi-)continuous, opaque and parallel reflections. It is bounded by the seabed on top (Fig. 6). We thus infer Facies 1 to be youngest. The thickness of Facies 1 ranges from $1 \mathrm{~ms}(\sim 1 \mathrm{~m})$ in distal and steep areas to max. $5 \mathrm{~ms}(\sim 4 \mathrm{~m})$ in ice-proximal areas. Both Facies 1 and 2 are abundant in Kongsfjorden and are particularly common in bathymetric depressions where together, they can be up to $11 \mathrm{~ms}(8 \mathrm{~m})$ thick.

The stratigraphic relationship between the facies varies locally. In ice-distal areas and away from the terminal moraines Facies 4 directly underlies Facies 2, which, in turn, directly underlies Facies 1 (Fig. 6b, d). In the iceproximal area of Kronebreen/Kongsvegen, however, Facies 1 directly overlies Facies 4 (Fig. 6). The differing relationship of Facies 3 to the other facies in the fjord suggests variable timing of deposition. Generally Facies 3 overlies and is thus considered younger than Facies 4 . In the case of RK3, however, Facies 3 onlaps onto Facies 2 (Fig. 6d), indicating that at this locality Facies 3 is also younger than Facies 2. 


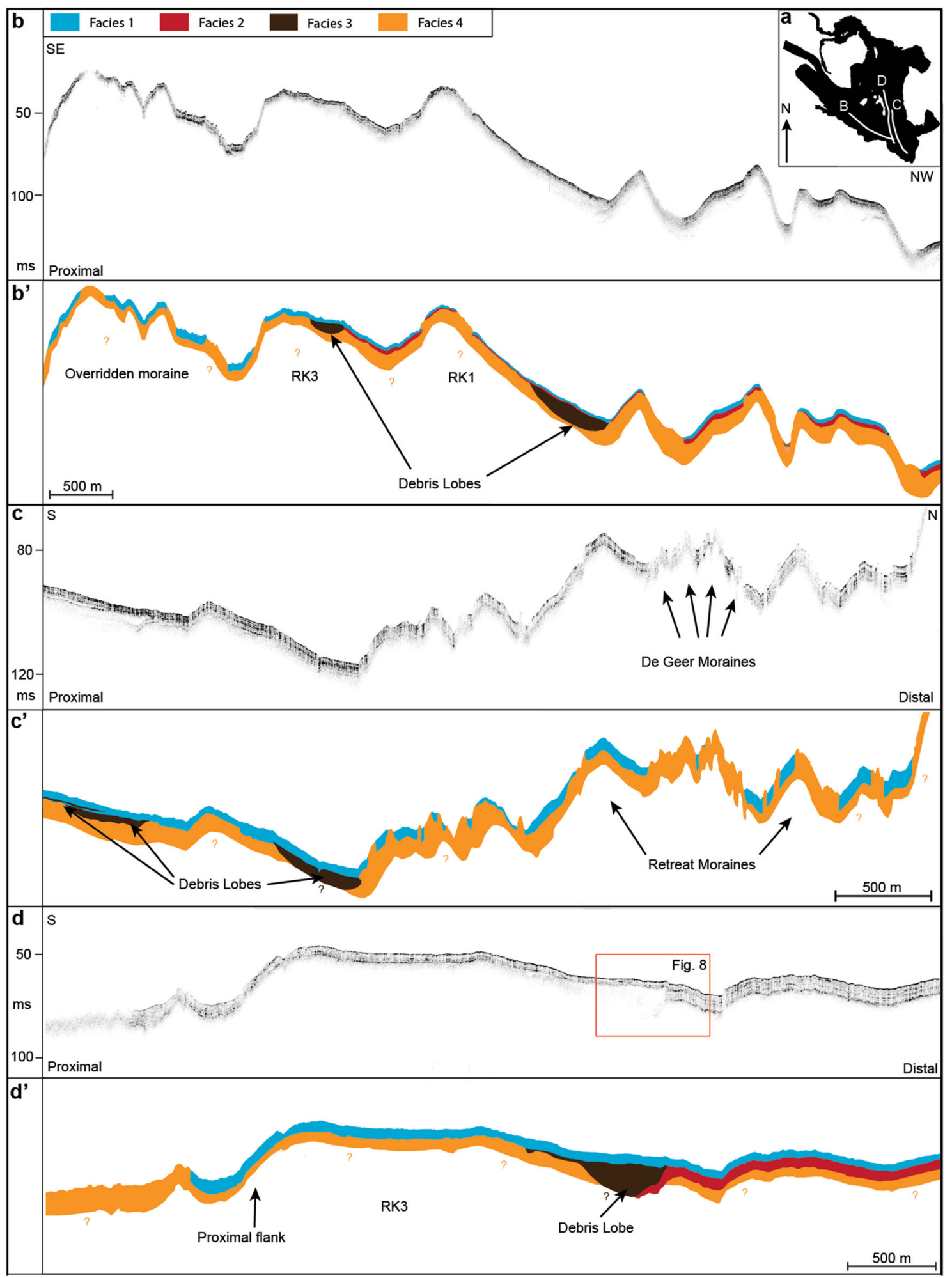

Fig. 6 a Black polygon showing the extent of the bathymetry with white lines showing the locations of $\mathbf{b}-\mathbf{d}$; b Chirp line 10JMGlaciBar025 with the $Y$-axis showing two-way travel time (TWT), and its facies interpretation in $\mathbf{b}^{\prime}$. Proximal and distal refer to the proximity to the Kronebreen/Kongsvegen ice margin; c Chirp line 10JM-GlaciBar038 with facies interpretation in $\mathbf{c}^{\prime}$; $\mathbf{d}$ Chirp line 10JMGlaciBar055 with facies interpretation in $\mathbf{d}^{\prime}$. Red rectangle indicates the extent of Fig. 8 
The acoustically massive appearance of Facies 4 (and 3) is suggested to reflect a mixed lithological composition. This, together with the facies' distribution within the fjord, leads us to interpret Facies 4 as acoustic basement. As this facies dominates on steeper slopes and in hummocky terrain (Fig. 6), and numerous glacier advances occurred, it is likely that the sediments are either bedrock or glacigenic sediments (cf. [32]), the latter possibly representing glacitectonite (sensu [27]) or subglacial till (see also [18]). From its onlapping character, its wedge-like shape and its close association with distal moraine slopes we infer that Facies 3 represents the debris lobes described in section "Large transverse ridges and lobe-shaped deposits: terminal moraines and debris lobes". Facies 3 is acoustically similar to sediment wedges from other Spitsbergen fjords (e.g. [63, $66,67]$ ), thus supporting our interpretations. The acoustic stratification of Facies 1 and 2 reflects repeated changes in the physical properties of the sediments most probably related to changes in grain size in a glacier-proximal environment (e.g. [32, 33, 67]). The differences in thickness between Facies 1 and 2 are explained by varying durations of deposition. In the case of Kongsvegen, which surged in 1948 [35], the uppermost sediments between the terminal surge moraine and the glacier front, i.e. Facies 1, accumulated over a maximum of 62 years (1948-2010), while the sediments of Facies 1 and Facies 2 beyond the surge moraine (RK3) accumulated over a much longer time period ( $>100$ years since the last advance, see Fig. $6 \mathrm{~d}$ ). The variable thickness of Facies 1 is probably related to the distance from the ice margin: in ice-proximal areas sedimentation rates are usually high, whereas they decrease exponentially with increasing distance from the glacier margin (e.g. [18]). We infer the bottom reflector of Facies 1 to represent the surge surface of 1948, and the bottom reflector of Facies 2 to represent the surge surface from 1869, when Kronebreen surged (cf. [18, 35]). The increased thicknesses of Facies 1 and 2 in bathymetric depressions might indicate elevated sediment input from the surrounding slopes. Facies 1, 2 and 3 have been sampled in the two sediment cores and their origin is discussed further in the next section.

\section{Lithology}

\section{Sedimentology}

A total of three lithological units are distinguished: Unit 3 is found at the base of GC02 (205-339 cm; Fig. 7a) and is inferred to be the oldest unit. It contains lighter and darker sharp-based layers of (reddish) brown clayey silt, that are a few millimeters to several centimeters thick. Scattered clasts occur throughout. Unit 2 is a matrix-supported, soft and water-rich diamict occurring at the base of GC01
(165-286 cm). It has a sharp upper boundary and contains abundant clasts distributed in a matrix of massive clayey silt. Unit 1 forms the uppermost, and therefore youngest unit in both sediment cores and extends from $0-165 \mathrm{~cm}$ in GC01 and from 0-205 cm in GC02 (Fig. 7a). Unit 1, like Unit 3, contains stratified clayey silt; however, the clast content is much higher. Clasts occur in concentrated layers or clusters or as randomly distributed lonestones (Fig. 7a). The boundary between units 3 and 1 in core GC02 is transitional.

We suggest that units 3 and 1 were deposited in a glacimarine environment where sedimentation occurred from suspension settling (mud) and ice rafting (clasts). This is in accordance with similar findings from Elverhøi et al. [17, 18]. Ice rafting probably occurred mainly from icebergs, but some contribution by sea ice is likely. The stratification of units 3 and 1 is probably related to recurring changes in the sediment source with varying contributions of meltwater from Kronebreen and Kongsvegen. Such variations could be due to changes in the glaciers' hydrology or seasonal variations in the rate of sediment delivery and discharge (cf. e.g. [80]). Based on the high water content, the massive internal structure and the variable grain size, we interpret the sediments of Unit 2 as reworked glacimarine sediments.

Measurements of the ${ }^{137} \mathrm{Cs}$ activity in the two sediment cores show a presence of ${ }^{137} \mathrm{Cs}$ in the upper $110 \mathrm{~cm}$ of both cores, with maximum activity at approximately $85 \mathrm{~cm}$. A secondary peak of ${ }^{137} \mathrm{Cs}$ activity appears in the uppermost $15 \mathrm{~cm}$ of GC02 (Fig. 7b). The ${ }^{210} \mathrm{~Pb}$ measurements reveal excess ${ }^{210} \mathrm{~Pb}$ in the upper $150 \mathrm{~cm}$ of both cores. These activities show an irregular profile in both cores, but generally decrease with depth (Fig. 7b).

The results of the ${ }^{137} \mathrm{Cs}$ activity measurements indicate that the upper $110 \mathrm{~cm}$ in both cores, i.e. large parts of Unit 1 , have likely been deposited after $\sim 1950$. Results further indicate that a sediment depth of approximately $85 \mathrm{~cm}$ in both cores is attributed to an age of 1962 AD (Fig. 7b). We thus infer that Unit 1 was deposited after the Kongsvegen surge in 1948 and reflects an increasingly ice distal environment during glacier retreat. As Unit 1 directly overlies Unit 2 in GC01, we deduce that the reworked sediments of Unit 2 were deposited as one of the debris flows described in section "Large transverse ridges and lobe-shaped deposits: terminal moraines and debris lobes" and represent the sediment lobe associated with RK1 (Figs. 6, 8). The stratigraphic relationship from the chirp data suggests the debris lobe from the 1948 Kongsvegen surge to be younger than Unit 3 (see section "Correlation of seismoand lithostratigraphy"). We suggest, therefore, that the base of Unit 3 was deposited during quiescent-phase conditions after the previous surge, and its uppermost parts 


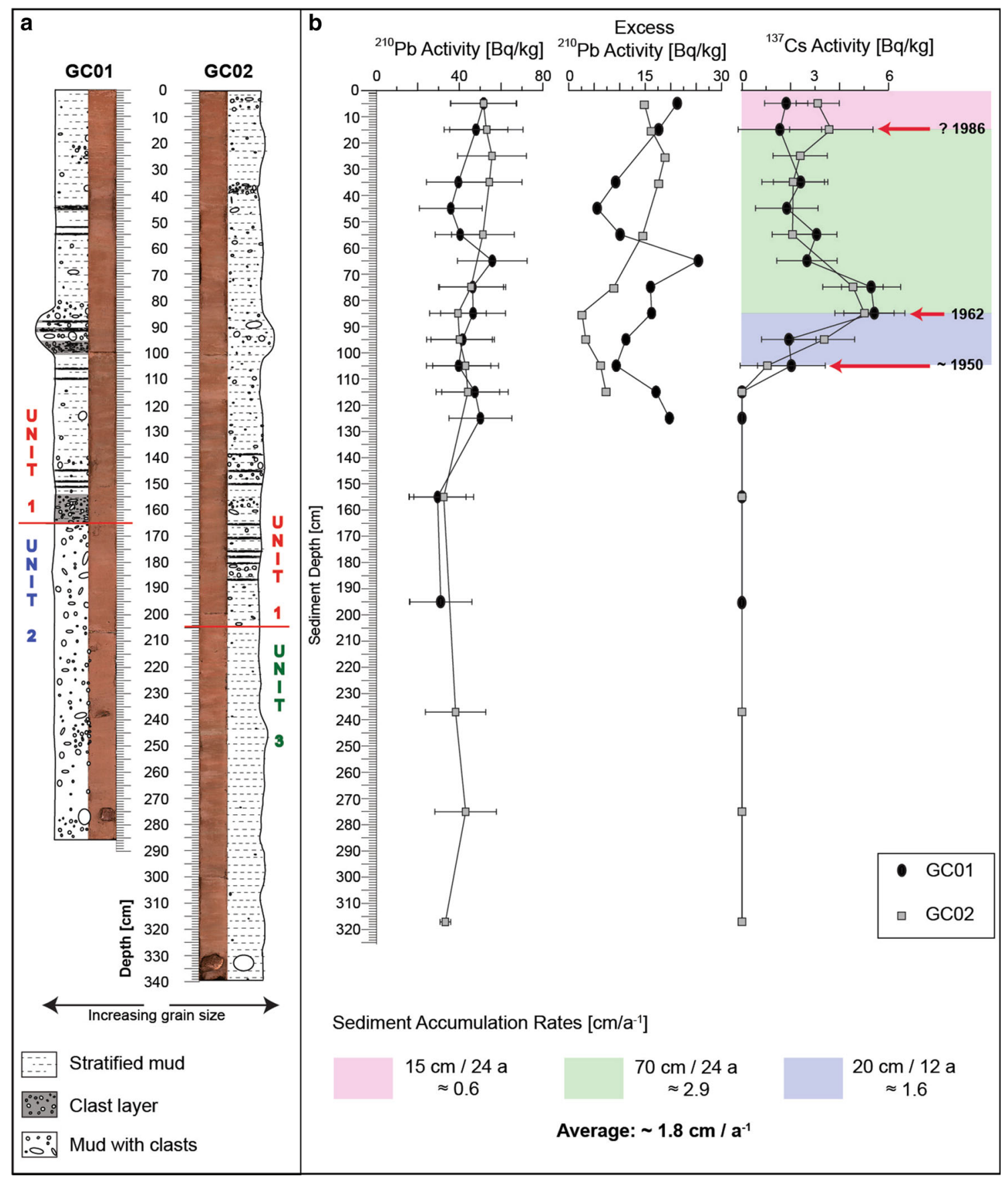

Fig. 7 a Logs and colour images of the sediments in the two cores GC01 and GC02. b Total ${ }^{210} \mathrm{~Pb}$, excess ${ }^{210} \mathrm{~Pb}$ and ${ }^{137} \mathrm{Cs}$ activity profiles for the sediment cores. Vertical error bars represent depth range of the sample, whereas horizontal error bars indicate 2-sigma

during the active phase of the 1948 surge. The relatively low number of clasts in Unit 3 could be explained by either a reduction in ice rafting or by high suspension rainout which swamped the contribution from IRD. The latter is most likely, as the high calving intensity of Kronebreen $\left(0.2247 \mathrm{~km}^{3} \mathrm{a}^{-1} ;[8]\right)$, the configuration of local ocean and wind currents and the warm water temperatures resulting measurement uncertainties. The derived age model provides approximate average sedimentation accumulation rates shown by the different colours in the ${ }^{137}$ Cs-plot

from increased inflow of Atlantic water are at odds with a low IRD delivery to the core sites (cf. [39, 42, 78]).

\section{Correlation of seismo- and lithostratigraphy}

We correlate seismic Facies 3 with lithological Unit 2 (reworked glacimarine sediment deposited from debris 


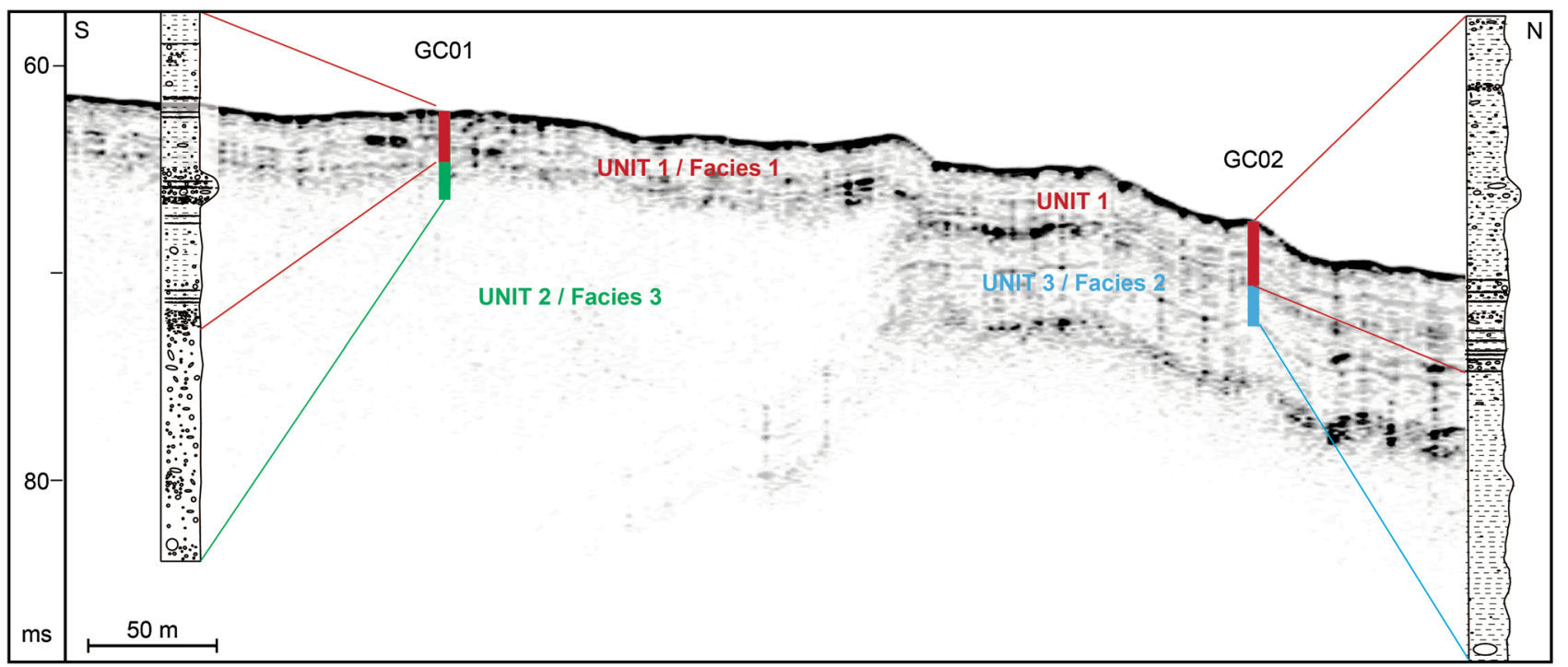

Fig. 8 Zoom-in of seismic line 10JM-GlaciBar055 (location indicated in Fig. 6d) showing location and penetration of the sedimentary units within the GCO1 and GCO2. Units 1,2 and 3 correlate with the seismic facies 1,3 and 2, respectively

flows triggered by surge activity), seismic Facies 2 with lithological Unit 3 (glacimarine muds deposited during glacier advance), and seismic Facies 1 with lithological Unit 1 (glacimarine muds deposited during glacier retreat; Fig. 8). The hiatus from Facies 1 to Facies 4 in the proximal parts of Kongsvegen/Kronebreen (Fig. 6) indicates that Unit 3 (Facies 2) was likely eroded here, probably as a result of glacial advance during the Kongsvegen surge.

\section{Sediment accumulation rates}

The age-depth relationship in both cores shows that the majority of Unit 1 was deposited with a calculated average sediment accumulation rate (SAR) of $1.8 \mathrm{~cm} \mathrm{a}^{-1}$ (Fig. 7b). The results of the ${ }^{137} \mathrm{Cs}$ activity measurements also indicate that the upper $15 \mathrm{~cm}$ in $\mathrm{GC} 02$ have probably been deposited since the Chernobyl-accident in 1986, which suggests a low SAR of $0.6 \mathrm{~cm} \mathrm{a}^{-1}$ for this portion of Unit 1 . In fact, ${ }^{210} \mathrm{~Pb}$ activity measurements suggest non-steady sedimentation conditions and thus variable SARs due to the irregular profile of excess ${ }^{210} \mathrm{~Pb}$. The measurements also show a minimum SAR for the uppermost $150 \mathrm{~cm}$ in both cores of $\sim 1.5 \mathrm{~cm} \mathrm{a}^{-1}$, which is in accordance with the ${ }^{137} \mathrm{Cs}$ dating. Note, however, that all rates presented here are minimum SARs, because the cores were taken with a gravity corer and the uppermost portion of the sediment cover may have been lost during sampling. This could, for example, explain the especially low SAR for the upper $15 \mathrm{~cm}$ of Unit 1 .

The overall decrease in excess ${ }^{210} \mathrm{~Pb}$ activity with depth in both cores (see Fig. 7b) is related to its radioactive decay with time. Despite the fact that generally excess ${ }^{210} \mathrm{~Pb}$ is measurable in sediments up to c. 100 years old [48], no excess ${ }^{210} \mathrm{~Pb}$ could be detected in sediments older than $\mathrm{c}$. 60 years in both cores (Fig. 7b). This could be due to the presence of sediments older than 100 years that were reworked and redeposited, or due to very high SAR causing dilution of the excess ${ }^{210} \mathrm{~Pb}$. The latter is particularly likely, because the top of the sediment lobe deposited during the Kongsvegen surge in 1948 was inferred to be located at $165 \mathrm{~cm}$ in core GC01, while a sediment depth of $110 \mathrm{~cm}$ dates to 1950 (according to the ${ }^{137} \mathrm{Cs}$ dating), thus suggesting a SAR of $\sim 30 \mathrm{~cm} \mathrm{a}^{-1}$ (i.e. one order of magnitude higher than the SAR after 1950). It should be noted that this is a minimum sediment accumulation rate as the exact time of deposition of the sediment lobe remains unknown. We ascribe this high accumulation rate to the proximity of the glacier front, which, based on the distance between terminal moraine and core site, was located approximately $2.5 \mathrm{~km}$ from the core site. According to Trusel et al. [82] and Kehrl et al. [45], recent SARs at the immediate fronts of Kongsvegen and Kronebreen are $>1 \mathrm{~m} \mathrm{a}^{-1}$. As exceptionally high discharge of turbid meltwater is common during and immediately after glacier surges (e.g. [6, 18, 34]), a former SAR of about $30 \mathrm{~cm} \mathrm{a}^{-1}$ at the core site seems reasonable. Such high accumulation rates are also in accordance with the low number of IRD in lithological Unit 3, which was linked to high input of fine-grained material from meltwater plumes, masking the contribution of IRD (see section "Sedimentology"). As the rate of sedimentation from suspension in glacimarine settings usually decreases exponentially with distance $[13,18,28$, $79,80]$, the relatively rapid decline of SARs later on may be related to rapid glacier retreat and the increasing distance between core sites and sediment source. This effect 
may have been enhanced by trapping of sediments within the basin between the terminal moraine and the retreating glacier front (cf. [46]).

\section{Discussion}

\section{Surge signatures in Kongsfjorden and comparison with other Spitsbergen fjords}

Each tidewater glacier in Kongsfjorden formed (1) glacial lineations during an advancing phase of fast ice flow, (2) terminal moraines when reaching maximum ice extent, (3) associated debris lobes on the moraines' distal slopes, and (4) De Geer moraines after the termination of the advance. In front of Blomstrandbreen and Kronebreen/Kongsvegen, overridden moraines reflect a terminal moraine and recessional moraines, respectively, which were modified during a later re-advance.

The observed landform assemblages are generally consistent with those observed for terrestrial surge-type glaciers (e.g. [22, 24]) and are also similar to submarine landform assemblages described for surge-type glaciers in other Spitsbergen fjords. This shows that the depositional models proposed by Plassen et al. [67], Ottesen and Dowdeswell [63], Ottesen et al. [66] and Flink et al. [29] are largely applicable also in Kongsfjorden. However, the occurrence of two different types of glacial lineations in the same fjord, as well as the presence of De Geer moraines appears to be unique to Kongsfjorden.

\section{Various types of glacial lineations}

Features similar to the smoother grooves and ridges from Kongsfjorden also occur in other Svalbard fjords, including Billefjorden [3], Lomfjorden, and Ymerbukta (Streuff, in prep.). Conversely, glacial lineations from Borebukta [63], Van Keulenfjorden, Rindersbukta [66], and Tempelfjorden [29], are more comparable to the sharp-crested lineations from Kongsfjorden. Thus the formation processes for the latter were probably similar to those for MSGL, even though the lineations in Kongsfjorden are of a much smaller scale. Possible explanations for this could be e.g. a less deformable substratum beneath the glacier, slower ice flow, shorter advances leaving insufficient time for the formation of larger features, or thinner glacier ice. Such differences between the individual glaciers could also account for the presence of both types of glacial lineations in Kongsfjorden.

\section{De Geer moraines}

De Geer moraines have been variously described in the literature $[14,56,86]$, but in fjords on Svalbard similar ridges have always been interpreted as either annual push moraines deposited during overall glacier retreat or as crevasse-squeeze ridges formed after surge termination $[10,29,63,66,74]$. Based on their dimensions and morphology, some of the De Geer moraines in Kongsfjorden appear similar to annual push moraines described from e.g. Borebukta and Yoldiabukta in Spitsbergen [63]. This is the case especially for the areas in front of Blomstrandbreen, Conwaybreen, and Kongsbreen South, where the longer, more continuous ridges could have been deposited from, and reflect the shape of, the grounding line (Fig. 5b, d). However, the number of De Geer moraines in front of the different glaciers is inconsistent with the number of elapsed years since the formation of the outermost moraine. Assuming that glacier retreat began shortly after moraine formation (cf. [29]), the 55 ridges in front of Blomstrandbreen suggest the outermost moraine (RK1) to be formed in 1955. However, RK1 is probably considerably older, as the glacier front was at least $1.5 \mathrm{~km}$ further inland in 1956 (see also section "Timing of landform formation" below). Furthermore, we would expect c. 113 ridges in front of Conwaybreen (rather than the observed 45), and c. 46 (rather than the observed 30) ridges in front of Kongsbreen South. We thus conclude that if the De Geer moraines in Kongsfjorden were formed from the same mechanism as (annual) push moraines from other fjords, the ridges in Kongsfjorden were formed at more irregular timescales (i.e. not annually).

In places the Kongsfjorden ridges exhibit a saw-tooth pattern in planform, which could be related to formation by a combination of longitudinal crevasse infill and sediment pushing at the glacier snout $[21,24,26,70]$. This could suggest that both processes were active in Kongsfjorden, and that the De Geer moraines thus reflect a combination of recessional push moraines and crevasse-squeeze ridges.

Although both, formation as end moraines or as crevasse-squeeze ridges, is possible, the almost perfect symmetry between proximal and distal slopes, the occasional cross-cutting of the ridges, a generally discontinuous character, and a largely similar pattern between crevasses and De Geer moraines (Fig. 9) suggest most of the moraines in Kongsfjorden to derive from crevasse-squeezing. Moreover, on the bathymetry data, the majority of the De Geer moraines appear more consistent with crevassesqueeze ridges (rather than annual retreat moraines) from Van Keulenfjorden, Rindersbukta [66] and Tempelfjorden [29]. In planform their pattern of distribution also compares with crevasse-squeeze ridges from terrestrial surge-type glaciers [22, 23], thus further supporting a crevassesqueeze origin.

Based on the above observations, we therefore suggest that the majority of the De Geer moraines in Kongsfjorden resemble crevasse-squeeze ridges. Nonetheless there are 


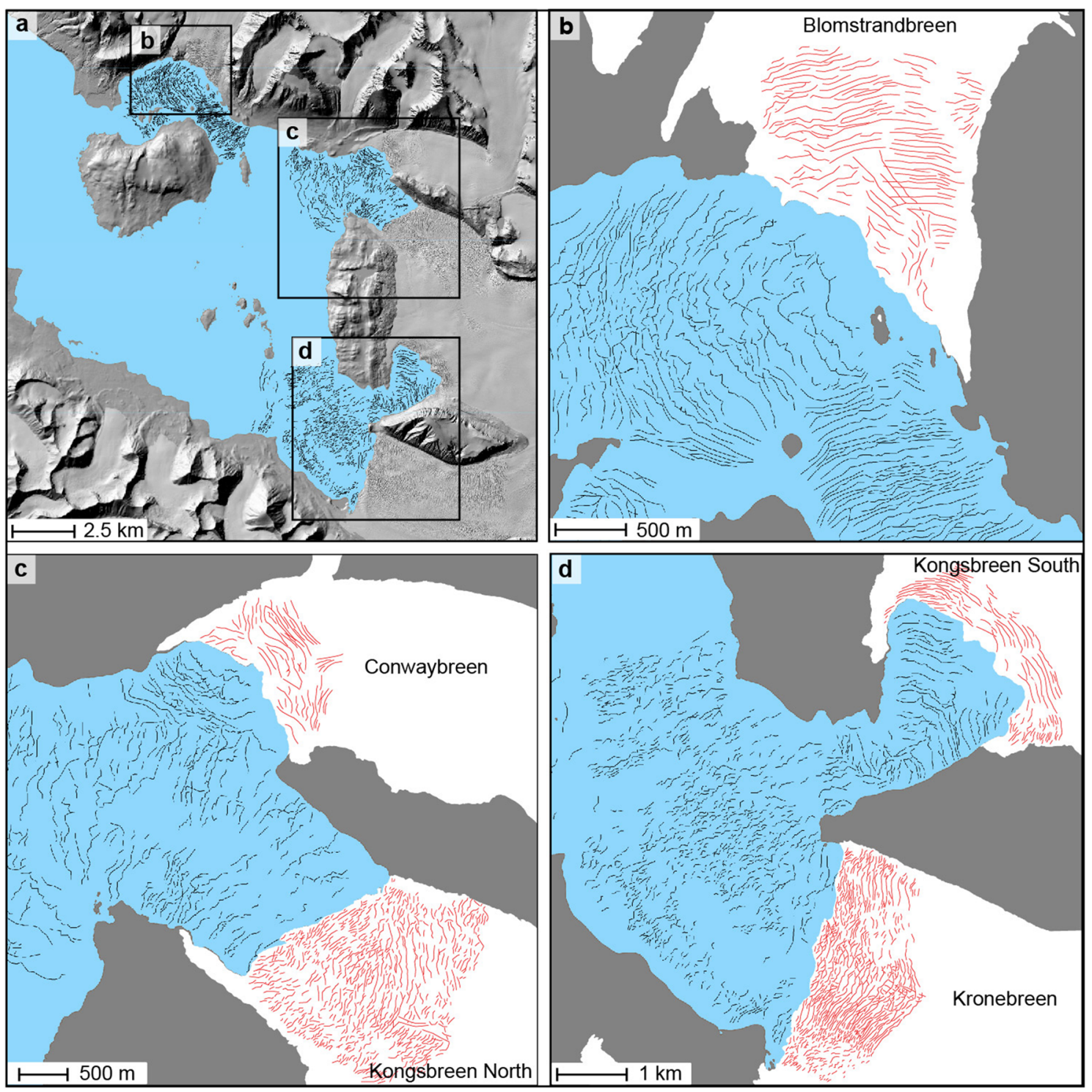

Fig. 9 a Map of De Geer moraines in Kongsfjorden with black rectangles showing locations of b-d. b-d show maps of De Geer moraines in front of (black lines) and crevasses on top of the glaciers (red lines)

also elements which are compatible with formation of some of the ridges as retreat moraines. This indicates that De Geer moraines associated with surging glaciers in Spitsbergen fjords form by a variety of processes and thus that submarine landform assemblages in front of surge-type glaciers are more diverse than previously described (cf. e.g. $[29,63,66,67])$.

\section{Timing of landform formation}

From correlation of the terminal moraines with known ice front positions [54], we infer that all the submarine glacial landforms in inner Kongsfjorden were deposited throughout the past 150 years. Registered surge years are 1869 for Kronebreen, 1948 for Kongsvegen and 1960 for
Blomstrandbreen [35]. RK1 was deposited around 1869 (Fig. 10) and probably marks the maximum extent of the Kronebreen surge. RK3 fits the 1948 position, when Kongsvegen surged (Fig. 10). RC1 also dates back to 1869, indicating that the Kronebreen surge caused a simultaenous advance of Kongsbreen North. RK2 and RC2 are close to ice front positions from 1897 (Fig. 10). Neither Kongsbreen nor Conwaybreen are documented to be of surgetype [35], hence it is possible that these moraines were deposited from a climatically induced advance during the Little Ice Age (LIA). However, the LIA is documented to have ended $\sim 1900 \mathrm{AD}$ (cf. [58]) and temperatures were probably warmer already in 1897 , making a purely climatic advance unlikely. Furthermore, the similarity between the landforms in front of Conwaybreen and Kongsbreen with 
Fig. 10 Terminal moraines in Kongsfjorden with respect to glacier front positions reconstructed by Liest $\varnothing 1$ [54] in front of a Blomstrandbreen $(R B 1,2,3)$ and Conwaybreen/ Kongsbreen North $(R C 1,2)$, and b Kronebreen/Kongsvegen $(R K 1,2,3)$. Max refers to the unknown year of Blomstrandbreen's maximum extent (cf. [54])

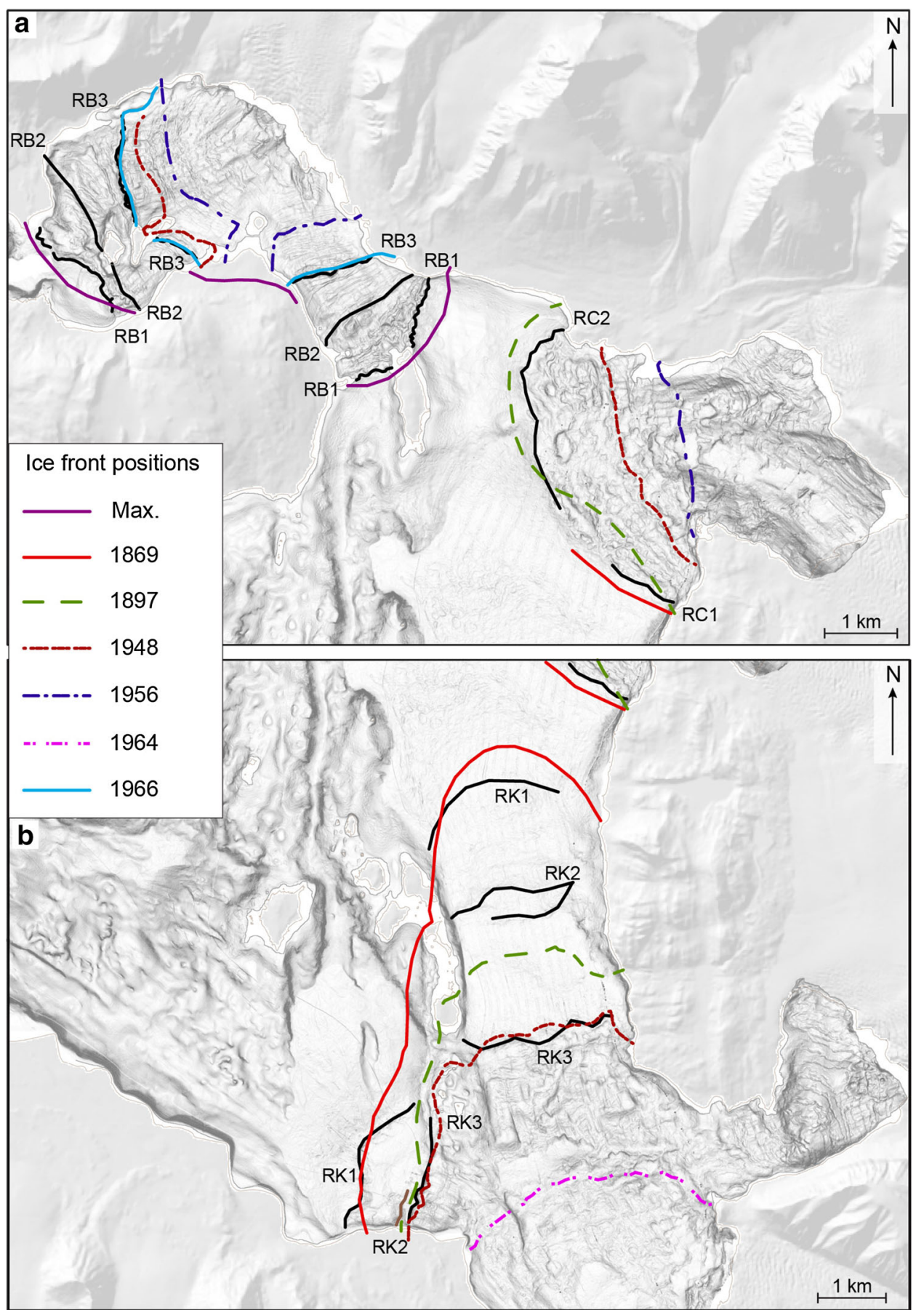

those in front of the surge-type glaciers (Blomstrandbreen, Kronebreen and Kongsvegen) could suggest that Kongsbreen did surge. The presence of De Geer moraines between RC2 and the present glacier fronts supports this and we thus infer that a Kongsbreen surge is the more likely scenario.

The ice front positions from 1956 and 1966, as well as the fact that Blomstrandbreen advanced $\sim 600 \mathrm{~m}$ during its active surge phase [54] strongly suggest RB3 to be the terminal surge moraine from 1960 (Fig. 10). Although the exact chronology of deposition of RB1 and RB2 is still pending, the overridden character of RB2 indicates that it is older than RB1.

We conclude that the geomorphological evidence from the landform assemblages in Kongsfjorden is consistent with surging, especially because (1) the positions of the terminal moraines largely coincide with the glacier front positions documented for respective surge years (cf. [54]), 
(2) the likely presence of De Geer moraines resembling crevasse-squeeze ridges is considered as possibly surgediagnostic, (3) glacial lineations in front of all the glaciers indicate fast ice flow, a characteristic of the active phase of a surge cycle [60], and (4) overridden moraines in front of Blomstrandbreen and Kronebreen/Kongsvegen are the product of multiple advances.

\section{Conclusions}

Multibeam and seismic investigations in inner Kongsfjorden reveal a variety of landforms that formed as a result of glacier surges during the past c. 150 years. These include (1) overridden (recessional) moraines from previous ice advance(s), (2) glacial lineations of two types: (a) smooth and (b) sharp-crested groove-ridge features of different sizes, both formed when basal sediments are deformed as a consequence of a rapidly advancing glacier. (3) Large transverse ridges mark the maximum glacier extent during a surge event and were deposited at the end of surges of Kronebreen in 1869, Kongsvegen in 1948, and Blomstrandbreen in 1960. Terminal moraines in front of Conwaybreen/Kongsbreen North and Kongsbreen South/ Kronebreen/Kongsvegen coincide with glacier front positions from $\sim 1897$, and suggest a Kongsbreen surge for that year. The distal flanks of most of the terminal moraines are characterized by the occurrence of (4) lobe-shaped debris flows resulting from sediment failure or pushing of sediments at the glacier front during the late stages of advance or shortly after. The formation of (5) De Geer moraines, occurred following surge termination and is linked to either crevasse-squeezing during the glacier's stagnant transitional phase and/or to sediment push from small re-advances/halts during overall retreat.

Suspension settling from meltwater plumes and ice rafting are dominant sedimentary processes in the fjord, leading to the deposition of stratified glacimarine muds with variable numbers of clasts. Reworking of sediments by glacier surging results in the deposition of sediment lobes containing massive silty clay with frequent clasts. Minimum sediment accumulation rates were $\sim 30 \mathrm{~cm} \mathrm{a}^{-1}$ approximately $2.5 \mathrm{~km}$ beyond the front of Kongsvegen after it reached its maximum surge extent in 1948, but rapidly decreased to an average rate of $1.8 \mathrm{~cm} \mathrm{a}^{-1}$ around 1950.

Acknowledgments This work, as part of the PetroMaks project "Glaciations in the Barents Sea area (GlaciBar)", was funded by the Research Council of Norway (RCN), Statoil, Det Norske oljeselskap ASA and BG group Norway (Grant 200672). It also contributes to the Research School in Arctic Marine Geology and Geophysics (AMGG) and to the Centre of Excellence "Arctic Gas Hydrate, Environment and Climate (CAGE)" at the Department of Geology, UiT-The Arctic
University of Norway. CAGE is funded by RCN (Grant 223259). The project was further funded by the European Commission FP7-People 2012-Initial Training Networks "Glaciated North Atlantic Margins (GLANAM)". Measurements of sediment accumulation rates were supported by Grant IP2010040970 from the Polish Ministry of Science and Higher Education and Grant 2013/10/E/ST10/00166 from the Polish National Science Center. We thank the captain and crew of R/V Helmer Hanssen (previously Jan Mayen) and Steinar Iversen for collecting and processing the data and are grateful to Monica Winsborrow and Rune Mattingsdal for collecting the sediment cores. Denise Christina Rüther and Lilja Rún Bjarnadóttir's assistance with the use of the software was greatly appreciated and Beata Sternal kindly helped with the laboratory analyses. The constructive feedback of two anonymous reviewers was also greatly appreciated.

Open Access This article is distributed under the terms of the Creative Commons Attribution 4.0 International License (http://crea tivecommons.org/licenses/by/4.0/), which permits unrestricted use, distribution, and reproduction in any medium, provided you give appropriate credit to the original author(s) and the source, provide a link to the Creative Commons license, and indicate if changes were made.

\section{References}

1. Andreassen K, Nilssen E, Ødegaard C (2007) Analysis of shallow gas and fluid migration within the Plio-Pleistocene sedimentary succession of the SW Barents Sea continental margin using 3D seismic data. Geo-Mar Lett 27(2-4):155-171

2. Appleby P (2008) Three decades of dating recent sediments by fallout radionuclides: a review. Holocene 18:83-93

3. Baeten N, Forwick M, Vogt C, Vorren T (2010) Late Weichselian and Holocene sedimentary environments and glacial activity in Billefjorden, Svalbard. Geol Soc Lond Spec Publ 344(1):207-223

4. Beaudry LM, Prichonnet G (1991) Late Glacial De Geer moraines with glaciofluvial sediment in the Chapais area, Québec (Canada). Boreas 20(4):377-394

5. Benn D, Evans D (2010) Glaciers and glaciation (2nd edn). Hodder Education, UK

6. Björnsson H, Pálsson F, Sigurðsson O, Flowers G (2003) Surges of glaciers in Iceland. Ann Glaciol 36(1):82-90

7. Blake KP (2000) Common origin for De Geer moraines of variable composition in Raudvassdalen, northern Norway. J Quat Sci 15(6):633-644

8. Błaszczyk M, Jania JA, Hagen JO (2009) Tidewater glaciers of Svalbard: recent changes and estimates of calving fluxes. Polish Polar Res 30(2):85-142

9. Boulton G (1986) Push-Moraines and glacier-contact fans in marine and terrestrial environments. Sedimentology 33(5):667698

10. Boulton G, Van Der Meer J, Hart J, Beets D, Ruegg G, Van Der Wateren F, Jarvis J (1996) Till and moraine emplacement in a deforming bed surge-an example from a marine environment. Quat Sci Rev 15(10):961-987

11. Clark C (1993) Mega-scale glacial lineations and cross-cutting ice-flow landforms. Earth Surf Process Landf 18(1):1-29

12. Clark CD (1994) Large-scale ice-moulding: a discussion of genesis and glaciological significance. Sediment Geol 91(1):253268

13. Cowan EA, Powell RD (1991) Ice-proximal sediment accumulation rates in a temperate glacial fjord, southeastern Alaska. Geol Soc Am Spec Pap 261:61-74

14. De Geer G (1940) Geochronologia suecica principles, vol 18. Almqvist \& Wiksells, Sweden 
15. Dowdeswell J, Hamilton G, Hagen J (1991) The duration of the active phase of surge-type glaciers: contrasts between Svalbard and other regions. J Glaciol 37(127):388-400

16. Dowdeswell J, Hodgkins R, Nuttall AM, Hagen J, Hamilton G (1995) Mass balance change as a control on the frequency and occurrence of glacier surges in Svalbard. Nor High Arct Geophys Res Lett 22(21):2909-2912

17. Elverhøi A, Liestøl O, Nagy J (1980) Glacial erosion, sedimentation and microfauna in the inner part of Kongsfjorden, Spitsbergen. Norsk Polarinstitutt Skrifter 172:33-58

18. Elverhøi A, Lønne Ø, Seland R (1983) Glaciomarine sedimentation in a modern fjord environment, Spitsbergen. Polar Res 1(2): $127-150$

19. Elverhøi A, Andersen E, Dokken T, Hebbeln D, Spielhagen R, Svendsen J, Forsberg C (1995) The growth and decay of the Late Weichselian ice sheet in western Svalbard and adjacent areas based on provenance studies of marine sediments. Quat Res 44(3):303-316

20. Evans D (2003) Ice-marginal terrestrial landsystems: active temperate glacier margins. Glacial Landsystems Arnold, London, pp $12-43$

21. Evans D, Orton C (2014) Heinabergsjökull and Skalafellsjökull, Iceland: active temperate piedmont lobe and outwash head glacial landsystem. J Maps 11(3):415-431

22. Evans D, Rea B (1999) Geomorphology and sedimentology of surging glaciers: a land-systems approach. Ann Glaciol 28(1):75-82

23. Evans D, Rea B (2003) Surging glacier landsystem. Glacial Landsystems Arnold, London, pp 259-288

24. Evans D, Twigg D (2002) The active temperate glacial landsystem: a model based on Breiðamerkurjökull and Fjallsjökull, Iceland. Quat Sci Rev 21(20):2143-2177

25. Evans D, Lemmen DR, Rea B (1999) Glacial landsystems of the southwest Laurentide Ice Sheet: modern Icelandic analogues. J Quat Sci 14(7):673-691

26. Evans D, Ewertowski M, Orton C Fláajökull (north lobe), Iceland: active temperate piedmont lobe glacial landsystem. J Maps (in press)

27. Evans DJA, Phillips E, Hiemstra J, Auton C (2006) Subglacial till: formation, sedimentary characteristics and classification. Earth-Sci Rev 78(1):115-176

28. Farrow GE, Syvitski JP, Tunnicliffe V (1983) Suspended particulate loading on the macrobenthos in a highly turbid fjord: Knight Inlet, British Columbia. Can J Fish Aquat Sci 40(S1):s273-s288

29. Flink AE, Noormets R, Kirchner N, Benn DI, Luckman A, Lovell $\mathrm{H}$ (2015) The evolution of a submarine landform record following recent and multiple surges of Tunabreen glacier, Svalbard. Quat Sci Rev 108:37-50

30. Forwick M, Vorren T (2007) Holocene mass-transport activity and climate in outer Isfjorden, Spitsbergen: marine and subsurface evidence. Holocene 17(6):707-716

31. Forwick M, Vorren T (2009) Late Weichselian and Holocene sedimentary environments and ice rafting in Isfjorden, Spitsbergen. Paleogeogr Paleoclimatol Paleoecol 280(1):258-274

32. Forwick M, Vorren T (2010) Stratigraphy and deglaciation of the Isfjorden area, Spitsbergen. Nor J Geol 90:163-179

33. Forwick M, Vorren T, Hald M, Korsun S, Roh Y, Vogt C, Yoo K (2010) Spatial and temporal influence of glaciers and rivers on the sedimentary environment in Sassenfjorden and Tempelfjorden, Spitsbergen. Geol Soc Lond Spec Publ 344(1):163-193

34. Gilbert R, Nielsen N, Möller H, Desloges J, Rasch M (2002) Glacimarine sedimentation in Kangerdluk (Disko Fjord), West Greenland, in response to a surging glacier. Mar Geol 191:1-18

35. Hagen J (1993) Glacier atlas of Svalbard and Jan Mayen, vol 129. Norsk Polarinstitutt Middelelser, Oslo
36. Hald M, Dahlgren T, Olsen TE, Lebesbye E (2001) Late Holocene paleoceanography in Van Mijenfjorden, Svalbard. Polar Res 20(1):23-35

37. Henriksen M, Alexanderson H, Landvik JY, Linge H, Peterson G (2014) Dynamics and retreat of the Late Weichselian Kongsfjorden ice stream, NW Svalbard. Quat Sci Rev 92:235-245

38. Hoppe G (1957) Problems of glacial morphology and the ice age. Geografiska Annaler 39:1-6

39. Howe J, Moreton S, Morri C, Morris P (2003) Multibeam bathymetry and the depositional environments of Kongsfjorden and Krossfjorden, western Spitsbergen, Svalbard. Polar Res 22(2):301-316

40. Ingólfsson O, Landvik J (2013) The Svalbard-Barents Sea icesheet-historical, current and future perspectives. Quat Sci Rev 64:33-60

41. Ito H, Kudoh S (1997) Characteristics of water in Kongsfjorden, Svalbard. Proc NIPR Symp Polar Meteorol Glaciol 11:211-232

42. Jernas P, Klitgaard-Kristensen D, Husum K, Wilson L, Koç N (2013) Palaeoenvironmental changes of the last two millennia on the western and northern Svalbard shelf. Boreas 42(1):236-255

43. Jessen S, Rasmussen T, Nielsen T, Solheim A (2010) A new Late Weichselian and Holocene marine chronology for the western Svalbard slope 30000-0 cal years BP. Quat Sci Rev 29(9):13011312

44. Kamb B (1987) Glacier surge mechanism based on linked cavity configuration of the basal water conduit system. J Geophys Res B 92(B9):9083-9100

45. Kehrl L, Hawley R, Powell R, Brigham-Grette J (2011) Glacimarine sedimentation processes at Kronebreen and Kongsvegen. Svalbard. Journal of Glaciology 57(205):841-847

46. Kempf P, Forwick M, Laberg J, Vorren T (2013) Late Weichselian-Holocene sedimentary palaeoenvironment and glacial activity in the high-Arctic van Keulenfjorden, Spitsbergen. Holocene 23(11):1607-1618

47. King E, Hindmarsh R, Stokes C (2009) Formation of mega-scale glacial lineations observed beneath a West Antarctic ice stream. Nat Geosci 2(8):585-588

48. Koide M, Soutar A, Goldberg ED (1972) Marine geochronology with $210 \mathrm{~Pb}$. Earth Planet Sci Lett 14(3):442-446

49. Kristensen L, Benn D, Hormes A, Ottesen D (2009) Mud aprons in front of Svalbard surge moraines: evidence of subglacial deforming layers or proglacial glaciotectonics? Geomorphology 111(3):206-221

50. Landvik J, Bondevik S, Elverhøi A, Fjeldskaar W, Mangerud J, Oea Salvigsen (1998) The last glacial maximum of Svalbard and the Barents Sea area: ice sheet extent and configuration. Quat Sci Rev 17(1-3):43-75

51. Larsen E, Longva O, Follestad BA (1991) Formation of De Geer moraines and implications for deglaciation dynamics. J Quat Sci 6(4):263-277

52. Lehman S, Forman S (1992) Late Weichselian glacier retreat in Kongsfjorden, west Spitsbergen, Svalbard. Quat Res 37(2): 139-154

53. Liestøl O (1969) Glacier surges in west Spitsbergen. Can J Earth Sci 6:895-898

54. Liestøl O (1988) The glaciers in the Kongsfjorden area, Spitsbergen. Norske geografiske Tidsskrifter 42:231-238

55. Lundqvist J (1981) Moraine morphology. Terminological remarks and regional aspects. Geografiska Annaler Ser A Phys Geogr 63:127-138

56. Lundqvist J (2000) Palaeoseismicity and De Geer Moraines. Quat Int 68:175-186

57. MacLachlan S, Howe J, Vardy M (2010) Morphodynamic evolution of Kongsfjorden-Krossfjorden, Svalbard, during the Late Weichselian and the Holocene. Geol Soc Lond Spec Publ 344(1):195-205 
58. Mangerud J, Landvik J (2007) Younger Dryas cirque glaciers in western Spitsbergen: smaller than during the Little Ice Age. Boreas 36(3):278-285

59. McKee B, Nittrouer C, DeMaster D (1983) Concepts of sediment deposition and accumulation applied to the continental shelf near the mouth of the Yangtze River. Geology 11:631-633

60. Meier M, Post A (1969) What are glacier surges? Can J Earth Sci 6:807-817

61. Murray T, Dowdeswell JA, Drewry DJ, Frearson I (1998) Geometric evolution and ice dynamics during a surge of Bakaninbreen, Svalbard. J Glaciol 44(147):263-374

62. Ó Cofaigh C, Dowdeswell J, Allen C, Hiemstra J, Pudsey C, Evans J, Evans D, (2005) Flow dynamics and till genesis associated with a marine-based Antarctic paleo-ice stream. Quat Sci Rev 24(5):709-740

63. Ottesen D, Dowdeswell J (2006) Assemblages of submarine landforms produced by tidewater glaciers in Svalbard. J Geophys Res 111(F01):016

64. Ottesen D, Dowdeswell J, Rise L (2005) Submarine landforms and the reconstruction of fast-flowing ice streams within a large Quaternary ice sheet: the 2500-km-long Norwegian-Svalbard margin $\left(57^{\circ}-80^{\circ} \mathrm{N}\right)$. Geol Soc Am Bull 117:1033-1050

65. Ottesen D, Dowdeswell J, Landvik J, Mienert J (2007) Dynamics of the Late-Weichselian ice sheet on Svalbard inferred from highresolution sea-floor morphology. Boreas 36:286-306

66. Ottesen D, Dowdeswell J, Benn D, Kristensen L, Christiansen H, Christensen O, Vorren T (2008) Submarine landforms characteristic of glacier surges in two Spitsbergen fjords. Quat Sci Rev 27(15):1583-1599

67. Plassen L, Vorren T, Forwick M (2004) Integrated acoustic and coring investigations of glacigenic deposits in Spitsbergen fjords. Polar Res 23(1):89-110

68. Raymond C (1987) How do glaciers surge? A review. J Geophys Res: Solid Earth (1978-2012) 92(B9):9121-9134

69. Robbins J, Edgington D (1975) Determination of recent sedimentation rates in Lake Michigan using Pb-210 and Cs- 137 . Geochimica et Cosmochimica Acta Acta 39:285-304

70. Sharp M (1984) Annual moraine ridges at Skálafellsjökull, southeast Iceland. J Glaciol 30:104

71. Sharp M (1985) Crevasse-fill-ridges-a landform type characteristic of surging glaciers? Geografiska Annaler Ser A Phys Geogr 67(3/4):213-220

72. Sharp M (1988) Surging glaciers: behaviour and mechanisms. Prog Phys Geogr 12(3):349-370

73. Solheim A (1991) The depositional environment of surging subpolar tidewater glaciers. Norsk Polarinstitutt Skrifter 194:1-97
74. Solheim A, Pfirman S (1985) Sea-floor morphology outside a grounded, surging glacier; Bråsvellbreen, Svalbard. Mar Geol 65:127-143

75. Sollid JL (1989) Comments on the genesis of De Geer moraines. Norsk Geografisk Tidsskrift-Nor J Geogr 43(1):45-47

76. Stokes C, Clark C (2002) Are long subglacial bedforms indicative of fast ice flow? Boreas 31(3):239-249

77. Strömberg B (1965) Mappings and geochronological investigations in some moraine areas of south-central Sweden. Geografiska Annaler Ser A Phys Geogr 47(2):73-82

78. Svendsen H, Beszczynska-Møller A, Hagen JO, Lefauconnier B, Tverberg V, Gerland S, Ørbøk J, Bischof K, Papucci C, Zajaczkowski M, Azzolini R, Bruland O, Wiencke C, Winther J, Dallmann W (2002) The physical environment of KongsfjordenKrossfjorden, an Arctic fjord system in Svalbard. Polar Res 21(1):133-166

79. Syvitski JP (1989) On the deposition of sediment within glacierinfluenced fjords: oceanographic controls. Mar Geol 85(2):301329

80. Szczuciński W, Zajaczkowski M (2012) Factors controlling downward fluxes of particulate matter in glacier-contact and nonglacier contact settings in a subpolar fjord (Billefjorden, Svalbard). Int Assoc Sedimentol Spec Publ 44:369-386

81. Szczuciński W, Zajaczkowski M, Scholten J (2009) Sediment accumulation rates in subpolar fjords-impact of post-Little Ice Age glacier retreat, Billefjorden, Svalbard. Estuar Coast Shelf Sci 85:345-356

82. Trusel L, Powell R, Cumpston R, Brigham-Grette J (2010) Modern glacimarine processes and potential future behaviour of Kronebreen and Kongsvegen polythermal tidewater glaciers, Kongsfjorden, Svalbard. Geol Soc Lond Spec Publ 344:89-102

83. Tulaczyk S, Scherer R, Clark C (2001) A ploughing model for the origin of weak tills beneath ice streams: a qualitative treatment. Quat Int 86:59-70

84. Zaborska A, Pempkowiak J, Papucci C (2006) Some sediment characteristics and sedimentation rates in an Arctic fjord (Kongsfjorden, Svalbard). Annu Environ Prot 8:79-96

85. Zajaczkowski M, Szczuciński W, Bojanowski R (2004) Recent changes in sediment accumulation rates in Adventfjorden, Svalbard. Oceanologia 46:217-231

86. Zilliacus H (1989) Genesis of De Geer moraines in Finland. Sediment Geol 62(2):309-317 